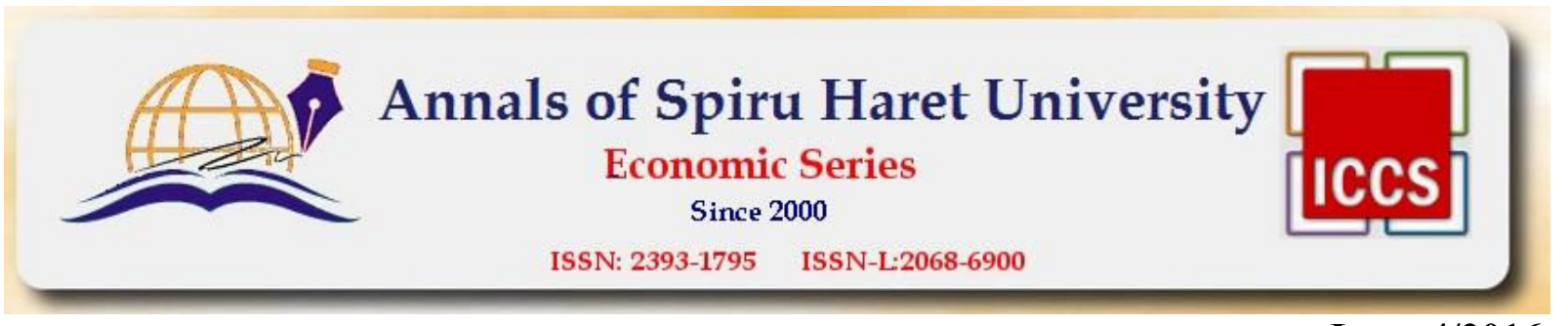

Issue 4/2016

\title{
CHANGE MANAGEMENT STRATEGIES RELATED TO THE GLOBAL ENVIRONMENT COMPLEXITY
}

\author{
Elena DOVAL \\ "Spiru Haret" University, Faculty of Juridicial, Economic and Administrative Sciences, \\ Braşov, Turnului Street, no. 7, Braşov, Romania, Tel.: +10212421208, Fax: +40212420781, Email: \\ prof_ed@gmail.com
}

\begin{abstract}
The changes in organizations appear as a reaction to the organizational environment changes. In order to manage these changes successfully, the managers need to anticipate and design alternative strategies by preparing different options. Nevertheless, the complexity of the global environment forces the managers to adopt strategies for their organizations that are facilitating the creation of new strategic competences and competitive advantages to face the environmental rapid changes. In this context, this paper is aiming to illustrate the main directions the change management may consider changing the organization strategies in order to harmonize them with the external environment, such as integration versus externalization, flexible specialization and flexible organization, standardization versus adaptation, market segmentation, relationship building and maintaining and communication integration. However, the new strategies are based on a changed attitude of the managers towards the competitive advantage that is dynamic and focused on creation rather than to operations.
\end{abstract}

Keywords: global environment complexity, management, change management, strategy, competitive advantage.

JEL Classification: L25, M21

\section{Introduction}

Changes in organizations occur as a reaction to changes in the organizational environment, and for them to have positive effects company managers must adopt strategies that lead to the preservation or development of competitive advantage.

Nohria and Ghoshal (1997) state that "the competitive advantage of an increase in multinational organizations the ability to create new value through accumulation, transfer and integration of different kinds of knowledge, resources and capabilities along dispersed organizational units".

The authors point out that the organizational changes associated with global integration have new technical capabilities by specific vehicles of network structures. These capabilities are built, on the one hand, by specific strategies of global organizations (alliances, acquisitions, joint venture, etc.) and secondly, through the combination of resources and capabilities accumulated from various units of global and localized alliance partners in new capabilities that are not available to any affiliated parties.

The specific features of company environment (complexity, uncertainty, limitation of skills and abilities) necessitate them to search for new management approaches that fit in with the new challenges (Gorzen-Mitka \& Okreglicka, 2014).

In the context of the global economy changing, this paper is aiming to illustrate the main directions the management may consider in order to change the organization strategies to harmonize them to the global environment. Using the ideas of the most known authors in the management literature, the paper emphasizes the main strategies that may change the organization and adapt it to the global changes. 


\section{Annals of Spiru Haret University \\ Economic Series \\ Since 2000}

ISSN: 2393-1795 ISSN-L:2068-6900

Issue 4/2016

\section{Global environment complexity}

One of the main conclusions in European Environment Agency (EEA)'s flagship report, SOER 2010 (The European environment - state and outlook), appears obvious: "environmental challenges are complex and can't be understood in isolation". This interconnectivity is often referred to as "globalization" and it's not a new phenomenon (EAA, 2011). Underdal (2010) also stresses that the complex environment can't be well understood.

According to Stampleton et al. (2004), the international environmental complexity is associated with volatility and risk. The environment complexity is a multidimensional construct (Cannon \& St. John, 2014). Nevertheless, the global environment is also dynamic. According to Reeves et al., 2013, the dynamic environments require a switching approach and the switching requires resources and information to flow readily across organizational boundaries.

The environmental risks relate to the entire ecosystem of the planet and although some are natural risks and others are caused by various activities; they are predominantly the responsibility of people as individuals or organizations (Negulescu, 2015a).

Coping with the complexity of today's business environment is not about predicting the future or reducing risk. It's about building the capacity, in yourself, your people, and the organization to adapt continuously and learn speedily, in order to maximize the chances of seizing fleeting opportunities (Seijts et al., 2010).

\section{Change management strategies}

The complexity of the global environment forces the managers to adopt strategies for their organizations that are facilitating the creation of new strategic competences and competitive advantages to face the environmental rapid changes.

The complex context in which it changes in the international environment makes the management to adopt a number of strategies to facilitate not only to reduce the forces against change but also to organizational success acting in the international or global. Based on the fact that changes in the international environment are not predictable, Williamson (1999) suggests building a portfolio of policy options and proposes that this process will follow four phases: discovery constraints hidden establish the most appropriate change processes, portfolio optimization options and combining planning with opportunism. In brief, Williamson's portfolio of options enables companies to face the complexity of the global environment by preparing alternative strategies.

The main directions the change management may consider to change the organization strategies in order to harmonize them with the external environment, such as integration versus externalization, flexible specialization and flexible organization, standardization versus adaptation, market segmentation, relationship building and maintaining and communication integration, as well as the global strategy, reunited in a conceptual model (fig. no. 1).

\section{Managers' attitude towards the competitive advantage}

The companies that operate internationally and globally are designing their strategies to search for new resources, developing new strategic skills and capabilities and to perpetuate them in the future. The international competences are based on a fundamental change of the management's attitude towards the competitive advantage, which is dynamic and directed towards creation rather than the operations. The companies do not focus on protecting the competitive advantage obtained through already old strengths, but through innovation, accumulation of new knowledge and experiences and discovering new resources and capabilities. 


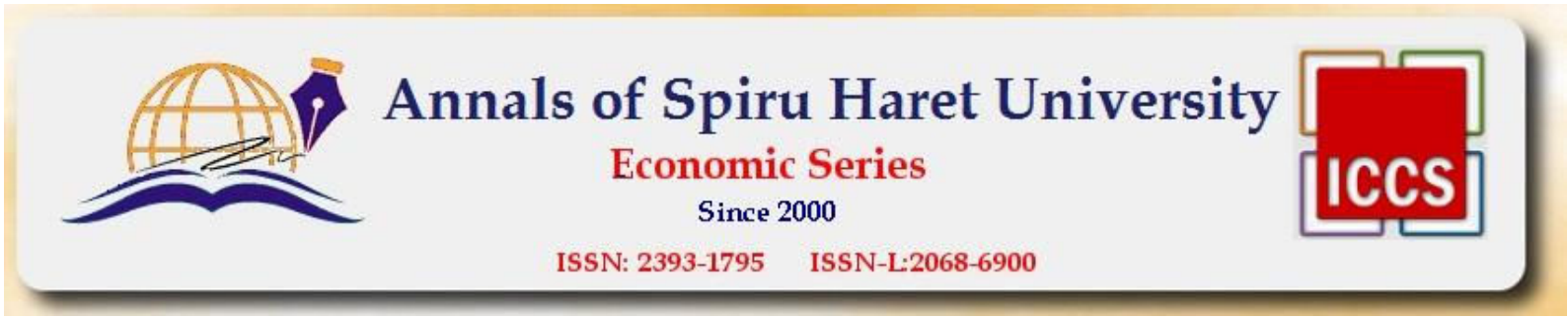

Issue 4/2016

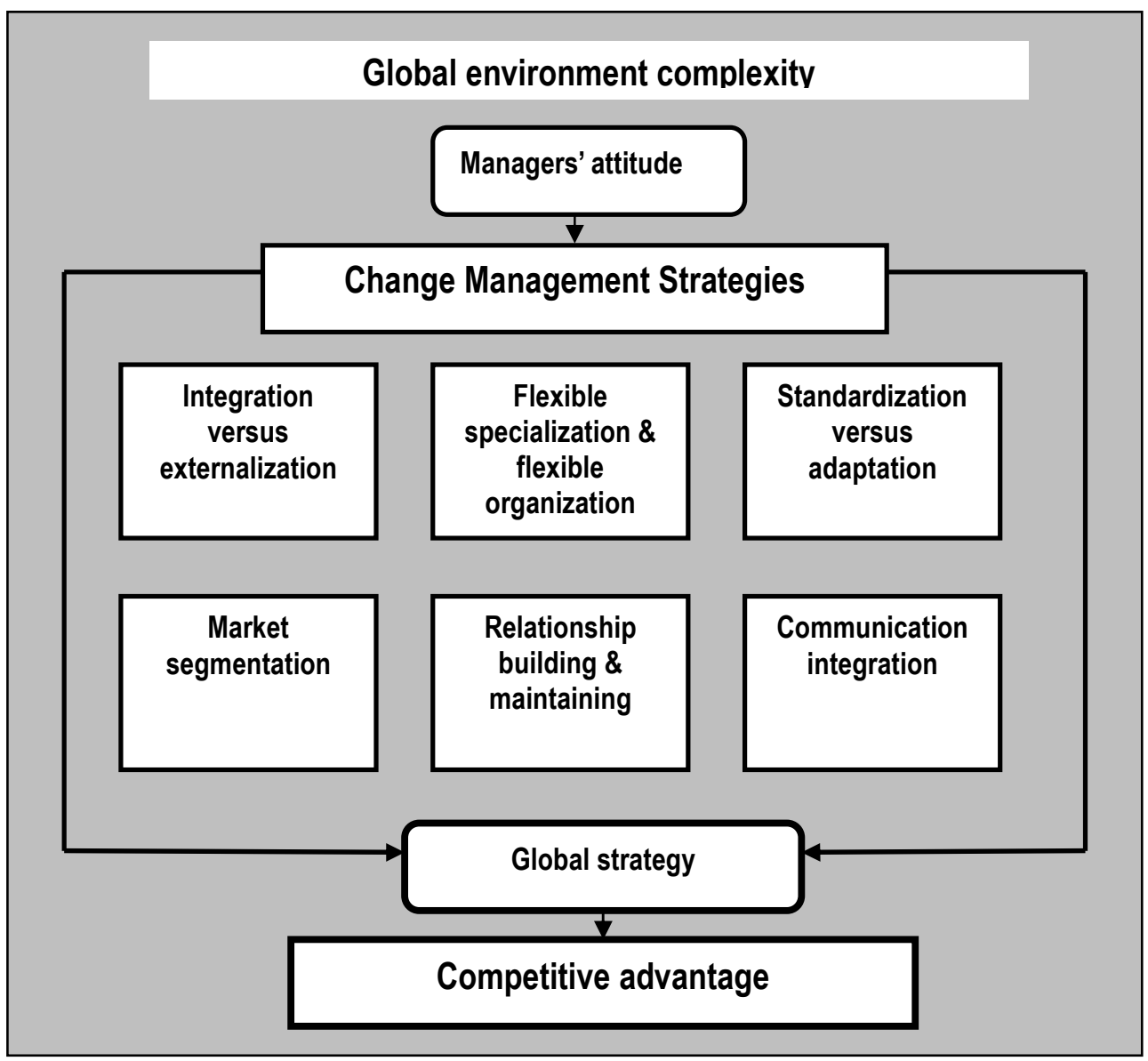

Figure no. 1. Organization Change Strategies conceptual model

\section{Integration versus externalization}

Vertical integration usually incurs high fixed costs. The policy to produce everything in the same company was specific to the planned economy and large state enterprises with over 10,000 employees. Major international organizations operating globally, with over 20,000 employees, adopt the same policy but do not face the problem of high indirect costs as administrative processes rely on outsourcing peripheral activities due to the inflexibility of the administrative system.

The harmonization of the two policies - integration and externalization - facilitates the access to economies of scale and competitive advantages resulting from the operations control and flexibility within organizations, low management, and indirect costs.

\section{Flexible specialization and flexible organization}

Flexible specialization represents the organization's response to the challenges of the competition by strategic mutations from the mass production to the specialized production. This change is possible through a continuous process of products' innovation and the implementation of the flexible processes, by integrating the small network of specialized subcontractors which have as the comparative advantage a high-level of technology and highly qualified personnel and information. The organization retains only core activities where the strategic competences create a competitive advantage. 


\section{Annals of Spiru Haret University \\ Economic Series \\ Since 2000}

ISSN: 2393-1795 ISSN-L:2068-6900

\section{Issue 4/2016}

Acting in the international environment, the large corporations include local organizations in the networks of the subcontractors supporting them financially and technically, thus having available local niche markets through the import of parts and re-export of finished products.

In order to increase the efficiency of the international environment management should adopt the strategy of the flexible organization.

According to Volberda (1998), the modern organizations must include a number of different features of classical organizations to be more successful without losing the competitive advantage already created. The transformation process would lead to change:

- The system: from the technical, rational, closed system to natural, based on learning and thinking, open-closed system.

- The structure: from mass production, differentiated structure, employment formal to network and subcontractors, flexible specialization, flexible systems and equipment, specialty, multi-specialist posts.

- In culture: from planning and control, vertical relationships, information formal preset targets to the fragmentation and action, mutual relations and collateral, informal information, speculative, group and individual targets.

This is achieved through the process of changing and adapting the organization classics, gaining features enabling the implementation of other strategies such as adaptation, outsourcing, and organizational networks.

\section{Standardization versus adaptation}

The standardization is the mass manufacture of products or services, specific economies of scale by applying computer technology and standardized marketing and sales systems with low-cost in the home country and exporting them to the international market.

The adaptation involves changes in technology, products, marketing and sales systems to meet the demands of consumers and beneficiaries of goods and services in the market segments in which they are to be exported.

The harmonization of these policies leads to a strategy for penetrating foreign markets. In this sense, Johansson (2000) points out that in many international activities, the core business that creates the intermediate product is standardized to achieve economies of scale and the final product is tailored to meet the local requirements.

Depending on the local conditions, the strategy of harmonization between standardization and adaptation can take different forms, such as standardized products and communication system adapted or adapted products and standardized marketing system.

\section{Market segmentation}

The increase in sales volume and the conquest of new markets are and will be the main strategic goals for any organization. The entering new markets can be achieved through consumers and beneficiaries market segmentation strategy.

McDonald and Dunbar (1998) propose that the segmentation strategy should comprise two main phases, namely: (1) the development of the market segments and (2) the selecting segments after classify them according to the priority, where there are 5 stages: market, customers and transactions, market segmentation, segment attractiveness and competitiveness of the organization, and also twelve work steps:

- analysis of market size, structure, trainers;

- buyer profile: consumers and beneficiaries;

- purchasing options: products and services requested; 
- buyers and goods and services purchased;

- buyers' needs; forming segments;

- combination of buyers, checking list of buyers; criteria of attractiveness of the organization;

- criteria ranking by importance; evaluation of the criteria using the main parameters;

- segments assessment and the attractiveness calculation; and

- organization's strengths on the market segment or competitiveness.

The process of market segmentation is particularly important for the management of any organization to provide scientifically different consumer groups and beneficiaries which they expect correlated with what the organization has as its competitive advantage.

\section{Relationship building and maintaining}

The strategy of building relationships that facilitate the activities in the international environment is focused on:

- promoting and encouraging the two-way communication;

- considering the position of the stakeholders in each country;

- ensuring trust, warmth, involvement and intimacy relations with partners in the host countries.

According to Berry (1995), the relationships with consumers and beneficiaries building is based on five strategic elements, out of which we name three:

- the developing services which build relationships (for example, key account management);

- the transfer from organizational relationships into individual relationships;

- the increase in core products or services with additional benefits.

\section{Communication integration}

The integration communication strategy means the organization as a brand in terms of its aims to create the image. According to Schultz and Kitchen (2000), the integrated communication involves the relationship management with the groups of the customer in a pluralistic, interactive and long term manner. They distinguish four characteristics of the integrated communication to create the image and the recognition for the organization:

- The integration of communication management needs a proper understanding of the dynamics of the buyers and potential buyers' voice. The relationships with them must be planned, implemented and monitored, and adjusted when necessary. This process is guided by strategic imperatives and longterm vision and involves various strategic alliances and relationships.

- Integrated communication is not an activity but a process involving the use of the entire diversified arsenal of the organization's communication.

- The communication is performed in both directions, interactive and with the purpose of mutual benefit. It is to identify, establish and maintain relationships with a diverse audience at national, regional, international and global levels.

- The public capable of influencing the organizational performance is pluralistic in terms of survival and organization's growth in the global environment.

The image is too important to be left to the hazard and, therefore, it must be created, strengthened and improved continuously to bring identity to the organization through strategic actions.

\section{Global strategy}

The Global Strategy has a specific organizational setting (Ghoshal, 1997). To be successful organizations have to fulfil three objectives:

(1) To be effective in the current operational activities by: 


\section{Annals of Spiru Haret University \\ Economic Series \\ Since 2000}

ISSN: 2393-1795 ISSN-L:2068-6900

Issue 4/2016

- exploiting the advantages offered by the differences in different countries (e.g., labour costs or cost of capital);

- economies of scale: expanding and volume;

- economies of scope: the investment and the costs to be allocated between the products, markets, and businesses or activities.

(2) To achieve effective management of risk through:

- balancing economy of scale by flexibility between strategic and operational actions;

- portfolio diversification and creation options on the comparative advantage of different countries.

(3) To develop innovation, learning and adaptation by:

- learning from differences between countries regarding management processes and systems;

- exploiting the advantages of accumulated experience (cost reduction, innovation);

- spreading the knowledge and learning throughout the organization (branches and locations in various countries) regarding the products, markets, and businesses or activities.

Nevertheless, for the business to be freely conducted under the laws of competition and the organizations to adopt strategies for change which gives them the competitive advantage, it is necessary that the global environment be free of global security threats. In this respect, the defence management worldwide has to consider the international existing opportunities and to develop some strategic actions to protect their countries and citizens: activities planning \& costing, including resource allocation; capacity building, risks management; defence personnel and civil people training; cooperation among the organizations; bilateral \& global alliances; diplomacy and cyber agreements (Negulescu, 2015 b).

\section{Conclusions and recommendations}

The global environment is complex, dynamic and volatile.

The companies acting globally or internationally - mostly the corporate - need to be aware of the complexity of the global environment in order to keep their competitive advantage or to gain it. In this respect, they need to adopt change strategies, among integration versus externalization, flexible specialization and flexible organization, standardization versus adaptation, market segmentation, relationship building and maintaining and communication integration or a global strategy.

Among the directions of actions resulting from the strategies briefly described above that the companies may consider there are:

- to prepare the company to learn from successes and mistakes;

- to invest in technology partnerships to ensure flexibility;

- to invest in foreign relations to gather knowledge from collaboration;

- to recruit innovative managers who appreciate teamwork;

- to understand the company's customers and their values, searching for the opportunities of communication and cooperation;

- to invest in network organization's structure, not only in infrastructure, and granting importance of cyber communication with suppliers and customers;

- to invest in branding to quickly gain competitive advantage;

- to develop new classes of products and services with computerized technology;

- to avoid accumulation of cash and investing money in new business development organization that creates opportunity and success;

- to prepare harmonized standardization with strategic adaptation and development of new related procedures;

- to outsource the auxiliary non-core business to reduce costs; 
- to redeploy operations in the host countries;

- to expand the company's activity from manufacturing to services, which are easier launched on the international market;

- to scan the environment continually to highlight the threats and opportunities;

- to plan the recession and prepare the revival strategy.

However, the complexity of the international environment may be confronted by implementing the best suitable organizational change strategies and by continuous adaptation to changing of the complex global environment.

This paper may be a useful insight for practical application of the management strategies briefly presented, but also for further development of management strategies by combining them and adding others appropriate to real situations.

\section{References}

1.Doval, E., Organizational Change Management in the International Environment (Info Market, Brasov, 2008), p. 8, 11.

2. Johansson, J.K., Global Marketing: Foreign Entry, Local Marketing and Global Management (McGrew Hill, London, 2000), p. 369.

3. Volberda, H.W., Building the Flexible Firm (Oxford University Press, Oxford, 1998), pp. 2627.

4. McDonald, M., \& Dunbar, I., Market Segmentation: How to Do It, How to Profit from It (Mcmillan Press Ltd., London, 1998), pp. 30-32.

5. Nohria, N. \& Ghoshal, S., The Differentiated Network (Jossey-Bass, San Francisco, USA, 1997), p. 208.

6. Sanders, H., Kim, K.S., Foster, S.F., El-Nameki, M.S.S., Economic Corporate Restructuring (Lansa Publishing B.V., Leiderdorp, The Netherlands, 1996), p. 1.

7. Schultz, D.E., \& Kitchen, J.K., Communicating Globally. An Integrated Marketing Approach (McMillan Press Ltd., London, 2000), pp. 58, 62-63.

8. Stapleton, T. et al., Marketing in a Complex World (MBA Course. The Open University, Business School. Milton Keynes, UK, Book 7, 2004), pp. 77-80.

9. Berry, L.L., "Relationship Marketing of Services - Growing Interest, Emerging Perspectives", in Journal of the Academy of Marketing Science, 1995, vol. 23, no. 4, pp. 236-245.

10. Buckley, P.J.; Casson, M.C., "Analzying foreign market entry strategies: extending the international approach", in Journal of International Business Studies, vol. 29, no. 3, 1998, pp. 539562.

11. Cannon, A.R. \& St. John, C.H., "Measuring Environmental Complexity. A Theoretical and Empirical Assessment", Organizational Reserch Methods, Sage journals, first published in 2008, vol. 10 , issue 2 , abstract.

12. Ghoshal, S., "Global Strategy: An Organizing Framework", in Strategic Management Journal, vol. 8, 1987, pp. 425-440.

13. Williamson, P.J., "Strategy as Options on the Future", Sloan Management Review, Spring, UK, 1999, pp. 118-126.

14. Gorzen-Mitka, I. \& Okreglicka, M., "Improving Decision Making in Complexity Environment", Procedia Economics and Finance, Elsevier, Volume 16, 2014, pp. 402-409, http://www.sciencedirect.com-/science/article/pii/S2212567114008193.

15. Seijts, G., Billou, N. \& Crossan, M., Coping with complexity, Ivey Business Journal, May/June 2010, http://iveybusinessjournal.com/-publication/coping-with-complexity.

16. Underdal, S., "Complexity and Challenges of Long-term Environmental Governance", in Global Environmental Change. Governance, Complexity and Resilience, Volume 20, Issue 3, August 2010, Elsevier, pp. 386-393, http://www.sciencedirect.com/science/journal/09593780/20/3. 


\section{Annals of Spiru Haret University Economic Series \\ Since 2000 \\ ISSN: 2393-1795 ISSN-L:2068-6900}

\section{Issue 4/2016}

17. Negulescu, O., "Approaches regarding the Management Strategy in the Global Green Industry", in Boldea, I. Debates on globalization identity through intercultural dialogue, Studies and Articles, Section: Social sciences and Management, Ed. Arhipelag XXI Press, Târgu Mureş, 2015, pp. 470-480.

18. Negulescu, O. (2015), "Threats and opportunities in actual defense management", Defense Resources Management, The $10^{\text {th }}$ Scientific conference with international attendance organized by the Regional Department of Defense Resources Management Studies, pp. 205-214.

19. Reeves, M., Haanaes, K., Hollingsorth, J. \& Scognamiglio Pasini, F.L., Ambidexterity: The Art of Thriving in Complex Environments, February 19, 2013, https://www.bcgperspectives.com/content/articles/business_unit_strategy_growth_ambidexterity_art_o f_thriving_in_complex_environments.

20. $\overline{\mathrm{EA}} \overline{\mathrm{A}}$, Complex challenges in an interconnected world, website article, last modified 31 August 2016, http://www.eea.europa.eu/signals/signals-2011/articles/complex-challenges-in-aninterconnected-world. 